\title{
İyimserlik ve Umutsuzluk Düzeyinin Yaşam Doyumu Üzerine Etkisi: Lise Öğrencileri Üzerine Bir Araştırma
}

\author{
The Effect of The Level of Optimism and Hopelessness on Life Satisfaction: \\ A Research on High School Students
}

\section{Dr. Öğr. Üyesi Altan Ayan}

Başvuru Tarihi: 23.03.2015

Kabul Tarihi: 02.06.2017

\section{Öz}

Araştırmanın amacı iyimserlik ve umutsuzluk düzeyinin yaşam doyumu üzerine etkisini incelemektir. Ayrica iyimserlik, umutsuzluk ve yașam doyumu değişkenleri ve alt boyutlarının demografik özelliklere göre farklılı gösterip göstermediği araştırılmaktadır. Örneklem Kırklarelindeki lise öğrencileri iken, evren Marmara Bölgesi genelindeki lise öğrencileridir. Bu kapsamda Kırklarelinde liselerde okuyan 1022 öğrenciden veriler toplanmıştır. Frekans analizi, faktör analizi, güvenirlik testi, kolmogorov-smirnov normallik testi, mann whitney u testi, kruskal wallis testi, çoklu regresyon testleri ve korelasyon testleri uygulanmıştır. Sonuçta iyimserlik ve soğukkanlllık düzeyi ile sosyallik ve uğraş bulma düzeyinin yaşam doyumunu arttırdığı görülmüş̧ür. Kötümserlik düzeyi yaşam doyumunu azaltmaktadır. Geleceğe olumlu bakış düzeyi yaşam doyumunu arttırmaktadır. Erkek öğrencilerin iyimserlik ve soğukkanlılık düzeyi kız öğrencilerden yüksektir. Aile geliri düşük olan öğrencilerin kötümserlik ve geleceğe olumsuz bakış düzeyleri diğerlerinden yüksektir. Not ortalaması çok yüksek olan öğrencilerin geleceğe olumlu bakış ve yaşam doyumu düzeyleri diğerlerinden yüksektir.

Anahtar Kelimeler: L̇yimserlik, Umut, Umutsuzluk, Yaşam Doyumu, Lise Öğrencileri

\begin{abstract}
The aim of study it is examined that the affect of the levels of optimism and hopelessness on life satisfaction. In addition it is investigated that whether or not the differences of variables of optimism, hopelessness and life satisfaction with the sub-dimensions according to demographic characteristics. While the sample are high school students in Kirklareli, the population are all of the high school students in the Marmara region. In this scope, data were gathered to 1022 high schools students in Kirklareli. Frequency analysis, factor analysis, reliability test, kolmogorov-smirnov normallity test, mann-whitney $u$, kruskal wallis, multiple regression tests and correlation tests were performed. As a result it is observed that the level of optimism and composure and the level of sociality and occupation increase to life satisfaction. The level of pessimism reduce to life satisfaction. The level of future positive view is increase to life satisfaction. The level of optimism and composure of male students were higher than female students. The level of pessimism and the level of future negative view of students with lower family income were higher than others. The level of future positive view and the level of life satisfaction of students with highest average score were higher than others.
\end{abstract}

Keywords: Optimism, Hope, Hopelessness, Life Satisfaction, High School Students

Dr. Öğr. Üyesi Altan Ayan, Trakya Üniversitesi Uzunköprü Uygulamalı Bilimler YO, altanayanayan@gmail.com 


\section{Giriş}

Kişilerin yaşamlarında iyimser ve umutlu olmaları kendilerine birçok yönden faydalar sağlar. İyimserlik duygusuna sahip bireylerin hayata daha olumlu bakması onların çeşitli üstünlükler kazanmasına yol açabilir. Hayata iyimser bakan kişiler daha kararlı olabilme, hedefleriyle yakından ilgilenme, olaylara olumlu bakabilme, zorluklar ve sorunlarla daha kolay başa çıma gibi olumlu yönlere sahiptir. Benzer olarak umut sahibi kişiler de geleceğe yönelik olumlu bakış açısına sahiptir. Umutsuzluk ise hayata olumsuz bakış açısı ve olumsuz beklentiler ile karakterize edilen bir kavramdır. İyimserlik, umut ve umutsuzluk kavramların özellikle lise çağındaki öğrenciler için önemi daha da fazladır. Lise öğrencileri hayatlarında iyimserlik ve umut sahibi iseler eğitimlerinde ve kişisel gelişimlerinde daha fazla ilerleyebilirler. İyimser ve umutlu öğrenciler eğitim alanında karşılaştıkları sorun ve sıkıntılar ile daha kolay başa çıkabileceklerdir. Umutsuzluk ise öğrenciler için ciddi olumsuzluklar meydana getirebilen ve mücadele edilmesi gereken bir durumdur. Umutsuz öğrencilerin hayatlarında pek çok sorun oluşacağından eğitim hedeflerine ulaşmada sorunlar yaşarlar. İyimser ve umutlu lise öğrencilerinin üniversite sınavlarına hazırlanırken sahip olduğu enerji ve motivasyon genellikle beklenen düzeyin üzerindedir. Bu kapsamda lise öğrencilerinin iyimserlik ve umut düzeyinin yükseltilmesine yönelik mekanizmalar önem kazanmaktadır. İyimserlik, umut ve yaşam doyumu kavramları olumlu sonuçlara yol açan unsurlar iken, umutsuzluk ise olumsuz sonuçlar meydana getirebilen bir kavramdır.

İyimserlik ve umut düzeyi yüksek öğrencilerin umutsuz öğrencilere göre yaşam doyumlarının daha fazla olması beklenir. İyimserlik ve umut düzeyi yüksek öğrencilerin yaşam doyumu da yüksek olabileceğinden bu öğrencilerin eğitim hedeflerine daha kolay ulaşacağı söylenebilir. Öğrencilerin umutsuzluk düzeylerinin yüksek olması yaşam doyumlarını azaltabilecek bir durumdur. Umutsuz öğrenciler eğitimlerine yönelik çeşitli sıkıntılarla baş etmede zorluk çekebilirler ve dolayısıyla yaşam doyumları azalabilir. Araştırmada yaşam doyumu üzerine iyimserlik ve umutsuzluk değişkenlerinin etki edip etmediği incelenmiştir. Bu kapsamda yaşam doyumunu arttıran başka bir deyişle öğrencilerin eğitim hedeflerini gerçekleştirmelerine katkı sağlayabilecek unsurlar belirlenmeye çabalanmıştır. Ayrıca iyimserlik, umutsuzluk ve yaşam doyumu düzeylerinin öğrencilerin demografik özellikleri- ne göre nasıl bir değişim gösterdiği araştırılmıştır. Bu açıdan iyimserlik, umut ve yaşam doyumuna olumlu etki eden demografik özellikler belirlenerek bunların geliştirilmesine yönelik faaliyetler desteklenebilir. Ayrıca umutsuzluk düzeyinin demografik özelliklere göre farklılıkları incelenerek umutsuzluğu azaltabilecek önlemler alınabilir. Bu çalışmada öğrencilerin yaşam doyumunu etkileyebilecek temel unsurlar olarak iyimserlik ve umutsuzluk değişkenleri ele alınmıştır. Çalışmada yaşam doyumuna olumlu ve olumsuz etkisi olabilecek değişkenler incelenmiştir. Çalışmada öğrencilerin eğitim hedefleri ve başarılarına olumlu etki edebilecek unsurlar araştırılmıştır. Öğrencilerin eğitim hedefleri ve başarılarını yükseltebilecek unsurların ortaya konulması önemlidir.

\section{İyimserlik, Umut, Umutsuzluk ve Yaşam Doyumu}

İyimserlik sağlıklı davranışlar ile ilişkili bir kavramdır. Örneğin, iyimserlik daha çok hareket yapmak, sağlıklı beslenme ve sağlıklı yemek alışkanlığı, stresi daha iyi yönetebilmek ve sigaradan kaçınmak gibi unsurlarla ilgilidir. İyimserlik kavramı kalıtsal bir bireysel özellik olmanın yanında aynı zamanda öğrenilebilir ve sosyal etkileme ile şekillendirilebilir. Bu nedenle iyimserlik sağlık sonuçlarının iyileştirilmesinde bir müdahale noktası olarak değerlendirilebilir (Kim, Chopik ve Smith, 2014). İyimserlik gibi pozitif psikolojik kaynaklar kişilere çevresel taleplerin üstesinden gelebilmelerine yardımcı olurlar. İyimserlik bir şeyler zor olduğunda bile olumlu sonuçlar ummak olarak tanımlanabilir. İyimserler olumlu sonuçlar beklediği için amaçlara ulaşmada gösterdiği çabalarda düşük iyimserlikteki kişilere göre daha 1srarcıdır (Eicher, Staerkle ve Clemence, 2014, s. 1022). Gelecekteki olaylar hakkında iyimser beklentiler sahibi olma eğilimi duygusallığı daha iyi ayarlama, fiziksel sağlık ve genel iyi oluş düzeyinin iyileşmesi ile ilişkilidir (Smith vd., 2013, s. 553). İyimserlik psikolojik iyi oluş düzeyinin daha yüksek olması, eğitim hedeflerinin sürdürülmesi konusunda yüksek istikrar, kişilerarası ilişkilerin daha iyi olması ve sosyal ağların oluşturulmasında büyük kolaylık sağlar. Yüksek iyimserlikteki kişiler olumsuz duygularına mani olurlar ve yakın ilişkiler kurmak için daha güçlü ve daha etkili çalışırlar. Böylece kişilerarası çatışmaları daha az yaşarlar. İyimser kişiler sağlıklarını teşvik edici davranışlarda bulunurlar (Carver, 2014). 
Umut kavramı iyimserlik ile yakından ilişkilidir ve genellikle pozitif psikolojik sonuçların kestirimcisidir. İyimserlik, başarı arayışının bir parçası olan yüksek hedeflere ulaşma inancı açısından mükemmeliyetçilikle ilişkili görülebilir (Black ve Reynolds, 2013, s.427). İyimserlik ve umut kavramları önemli kavramsal benzerliklere sahiptir. Her ikisi de genellikle kişinin kendi geleceğinin müreffeh ve elverişli olacağına ilişkin inancını yansıtan kararlı kişilik özellikleridir. Bu iki kavram arasında kayda değer farklılıklar da mevcuttur. İyimserlik olumlu genelleştirilmiş sonuç beklentileri olarak tanımlanabilir. Umut kavramı ise birbiriyle ilişkili iki farklı boyut barındırmaktadır. Bunlardan ilki kişinin amaçlarına erişme azmi ile ilgili iken, ikincisi ise kişinin amaçlarını sürdürebilmedeki olanaklarıyla ilgilidir. İyimserlikle kıyaslandığında umut kavramı daha açık olarak kişinin kendine başarılı bir gelecek yaratabilmek için kendisi tarafından başlatılan eylemleri içermektedir (Alarcon, Bowling ve Khazon, 2013, s. 821-822). İyimserlik, gelecekte olumlu olayların fazla olacağ 1 ve olumsuz olayların az olacağına ilişkin genelleştirilmiş beklentilerdir. İyimserlik ve umut birbiriyle ilişkili ve birçok ortak karakteristiklere sahip olmasına rağmen kavramsal ve ampirik açıdan farklı kavramlardır. Bununla beraber umut belirli hedeflere kişisel olarak ulaşılması ile daha fazla ilgiliyken, iyimserlik genel olarak gelecekte olumlu sonuç beklentileri ile alakalıdır (Strauss vd., 2014). Umut yaşam üzerinde güçlü bir etkiye sahip evrensel bir kavramdır. Umut hedeflere ulaşmada geleceğe yönelik beklentilerdir. Umut kavramı mutluluk, azim, başarı ve sağlık ile ilgilidir. Umut zihinsel stres etkilerini durdurucu rol oynar. Umut bireyin sahip olduğu bir kavram olarak teorileştirilmekte ve kişi yaşamda önemli ölçüde stresle yüz yüze kaldığında başa çıkmasına yardımcı olmaktadır. Umutun yüksek düzeyde olması psikolojik sıkıntıların azalması ile ilgilidir (Carretta, Ridner ve Dietrich, 2014).

Umutsuzluk, umut kavramının aksine kişinin içinde bulunduğu durum ve gelecekte karşı karşıya kalacağı birçok soruna yönelik olumsuz bakışa sahip olmas1dır. Umutsuzluk kişinin bilişsel yapısı ile yakından bağlantılıdır. Bilişsel yaklaşıma göre kişinin kaygı, kızgınlık ve umutsuzluk gibi duyguları yaşamasının temelinde olayların kendisinden ziyade olaylara dönük beklenti ve yorumlar vardır (Kodan, 2013, s. 176). Umut kavramında planların başarılacağına yönelik öngörü mevcutken, umutsuzluk ise başarısızlık yargısı içerir. Umutsuzluk geleceğe yönelik olumsuz beklentiler olarak açıklanabilir. Umutsuzluk kavramı günümüzde intiharı anlamak için önemli bir psikolojik unsur olarak görülmektedir. Umutsuzluğun yaşama isteğini düşürdüğü ve intihar düşüncelerini arttırdığ 1 söylenebilir (Tümkaya, 2005). Umutsuzluk kavramı olumsuz beklentiler ile karakterize edilen bilişsel/motivasyonel bir durumdur ve depresyonun temelini teşkil eder. Umutsuzluk kavramının depresif sendrom ile intihar davranışı arasında önemli bir aracılık rolü vardır. Umutsuzluk kavramı kapsamında iki kutuplu boyuttan söz edilebilir. Buna göre umut ve umutsuzluk ayrı dayanak noktaları olarak bu kutupları oluşturur (Velting, 1999). Umutsuzluk geleceğin olumsuz veya kötümser bakış açısıyla görülmesidir. Geleceğe olumsuz bakış depresyonun karakteristiği olan bilişsel üçlünün parçasıdır. Umutsuzluk yaşamdaki stres veya stresin yol açtığı intihar davranışları için aracılık rolü üstlenebilir (Daniel ve Goldston, 2012).

Umutsuzluk kavramının ölçülmesi ile ilgili olarak 20 soruluk Beck Umutsuzluk Ölçeği(Beck Hopelessness Scale) 1974 yılında yayınlanmış ve yüzlerce araştırmada kullanılmıştır (Lester, 2015). 1974 yılında yayınlanan Beck umutsuzluk ölçeği, umutsuzluğu ölçmek için geliştirilmiş önemli bir araçtır. Bu ölçek geliştirilene kadar umutsuzluk kavramını tanımlamak ve nesnel olarak ölçmek oldukça zor ve bu konuda anlamlı bir ölçek bulunmamaktaydı. Beck umutsuzluk ölçeği, umutsuzluk kavramının ölçülmesinde kullanılan en yaygın ölçektir. Bu ölçek intihar düşüncesi, intihar girişimi ve intihar unsurlarının önemli bir kestirimcisidir. Umutsuzluk ile intihar eğilimi arasındaki ilişkileri inceleyen birçok araştırmanın yanında umutsuzluk depresyon ilişkisini değerlendiren de birçok çalışma vardır. Depresyon ile umutsuzluk arasındaki korelasyon çok yüksek bulunmakta ve umutsuzluk genellikle depresif bir hastalık olarak görülmektedir (Hanna vd., 2011). İntihar girişimleri ile ilgili birçok araştırma umutsuzluk kavramına odaklanmaktadır. Umutsuzluk belirli hedeflerin elde edilmesine yönelik düşük düzeydeki beklentiler ve başarıya ulaşma olasılığına inancın azalması olarak açıklanabilir. Umutsuzluk kişisel boşluk duygusu, motivasyon kaybı ve gelecekteki beklentilere yönelik başarısızlık algısı, sstırap çekme ya da olumsuz kişisel sonuçlar ile birlikte gelişis. Umutsuzluk ve intihar eğilimi arasındaki ilişkilere yönelik birçok çalışma yapılmıştır (Spirito ve Overholser, 2003, s. 89-90). 
Yaşam doyumunun bireyin kendi kriterlerine göre yaşam kalitesini genel anlamda değerlendirilmesi neticesinde oluştuğu söylenebilir. Yaşam doyumu kişinin ne istediğine ilişkin önceden saptadığ yaşam standartları ile nelere sahip olduğuna ilişkin güncel durumunu kıyaslaması neticesinde elde ettiği sonuca bağlı oluşur. Kişinin istekleri ile başarıları arasındaki uyumsuzluk düzeyinin azalması yaşam doyumunu artması anlamına gelir (Akgündüz, 2013, s. 183). $\mathrm{Bu}$ konuda gerçekleştirilen önceki araştırmalara göre yaşam doyumu ile yüksek özsaygı, yüksek sosyal destek ve daha iyi yaşam koşulları arasında pozitif yönlü bir ilişki olduğu söylenebilir (Zhang, Zhao, Lester ve Zhou, 2014, s. 18). Yaşam doyumu, kişinin kendi hayatını bir bütün olarak değerlendirmesini yansıtan bir kavramdır (Zhao, Wang ve Kong, 2014). Yaşam doyumu, bireyin kendi genel yaşam deneyimleri hakkındaki yargısıdır ve iyi oluş kavramının önemli bir bileşenidir. Yaşam doyumuna ilişkin bireysel farkl1lıklar farklı değişkenler tarafından açıklanmaktadır. Bu kapsamda iki temel teorik model ortaya konulmuştur. Bunlardan ilki kişilik özellikleri değişkenlerinin rolünü vurgulayan yukarıdan aşağıya(top-down) yaklaşımdır. İkincisi ise durumlar, olaylar ve şartların rolüne odaklanan aşağıdan yukarıya (bottom-up) yaklaşımdır. Ayrıca medeni durum ve sosyo-ekonomik durumlar yaşam doyumu ile ilişkili olabilir (Matud, Bethencourt ve Ibanez, 2014).

Yaşam doyumu genel yaşam kalitesinin öznel bir değerlendirmesi olarak açıklanabilir. Olumsuz yaşam doyumu duygusal kargaşa, yeme bozuklukları ve intihar ile ilişkilidir (Lu vd., 2015). Yaşam doyumu bir kişinin kendi hayatını beğenmesi, onaylaması ve hayatından memnuniyet duymasıdır. Yaşam doyumu belirli tek bir durumla ilgili doyum olmayıp yaşama ilişkin tüm boyutları barındırmaktadır. Yaşam doyumu bireyin belirli bir durum karşısında değil de kendi hayatının bütününe yönelik tatminidir. Yaşam doyumunu yüksek algılayan kişiler daha anlamlı bir yaşam sürer ve kendileri açısından önem teşkil eden amaç ve değerlerini başkalarıyla paylaşırlar (Turgut ve Mert, 2014, s. 81). Yaşam doyumu olumsuz ruh halinin düşük düzeyde olması ve hoş duygular yaşanmasını içeren farklı ve geniş kategorilerde ele alınan bir kavramdır. Yaşam doyumunun yüksek olması sağlığın korunmasına yardımcı bir etkendir (Fastame, Penna ve Hitchcott, 2015). Yaşam doyumu kişinin kendi kriterleri bazında bütün yaşamını olumlu değerlendirmesidir. Bu kavram kişinin kendisine yüklediği kriterler ile kendi hayat şartlarını algılaması arasındaki kıyaslamaları yani kişinin kendi yaşamına ilişkin değer biçmesini içerir. Yaşam doyumu ile cinsiyet ve gelir düzeyi ilişkisini ele alan çalı̧̧malar yapılmıştır (Çeçen, 2007).

\section{Araştırma}

\section{Araştırmanın Amacı, Örneklem, Evren ve Ölçümm Araçları}

Araştırmanın amacı lise öğrencilerinin iyimserlik ve umutsuzluk düzeylerinin yaşam doyumları üzerine etkisini incelemektir. Buna ilave olarak iyimserlik, umutsuzluk ve yaşam doyumunun sosyo-demografik özelliklere göre farklılıkları incelenmektedir. Başka bir deyişle demografik özelliklerin iyimserlik, umutsuzluk ve yaşam doyumu üzerine etkisi araştırılmaktadır. Araştırmanın örneklemi Kırklareli’ndeki lise öğrencileridir. Bu kapsamda Kırklareli'nde çeşitli liselerde okuyan 1022 öğrenciden veriler toplanmıştır. Araştırmanın evreni ise Marmara bölgesi genelindeki lise öğrencileridir. Araştırmada iyimserliği ölçmek için orjinali Scheier ve Carver (1985) tarafindan geliştirilen 12 soruluk ölçek(The Life Orientation Test-LOT) kullanılmaktadır. Bu ölçeğin uyarlaması Aydın ve Tezer (1991) tarafından yapılmıştır. Ölçekte olumlu ve olumsuz yönlü sorular mevcuttur. Araştırmada umutsuzluk düzeyini ölçmek için 20 soruluk Beck Umutsuzluk ölçeği kullanılmaktadır. Ölçeğin orjinali Beck vd. (1974) tarafından geliştirilmiştir. Ölçeğin geçerlik ve güvenirliği Seber vd. (1993) tarafından yapılmıştır. Ölçek daha önce birçok araştırmada kullanılmıştır. Ölçekte olumlu ve olumsuz yönlü sorular vardır. Çalışmada yaşam doyumunu ölçmek için Diener vd. (1985) tarafından geliştirilen 5 soruluk ölçek (the Satisfaction with Life Scale) kullanılmaktadır. Ölçek Köker (1991) tarafından Türkçeye uyarlanmıştır.

\section{Araştırma Modeli ve Hipotezler}

Araştırma modeline göre iyimserlik ve umutsuzluk düzeyi yaşam doyumuna etki etmektedir. İyimserlik düzeyinin yaşam doyumu üzerine etkisine ilişkin bir çoklu regresyon modeli denenmektedir. Umutsuzluk düzeyinin yaşam doyumu üzerine etkisine iliş̧kin bir çoklu regresyon modeli test edilmektedir. $\mathrm{Bu}$ kapsamda iki ayrı hipotez test edilmektedir. Ayrıca araştırmada iyimserlik, umutsuzluk ve yaşam doyumunun demografik özelliklere göre farklılık gösterip göstermediği araştırılmaktadır. Bu kapsamda mann whitney u ve kruskal wallis testleri uygulanmıştır. 


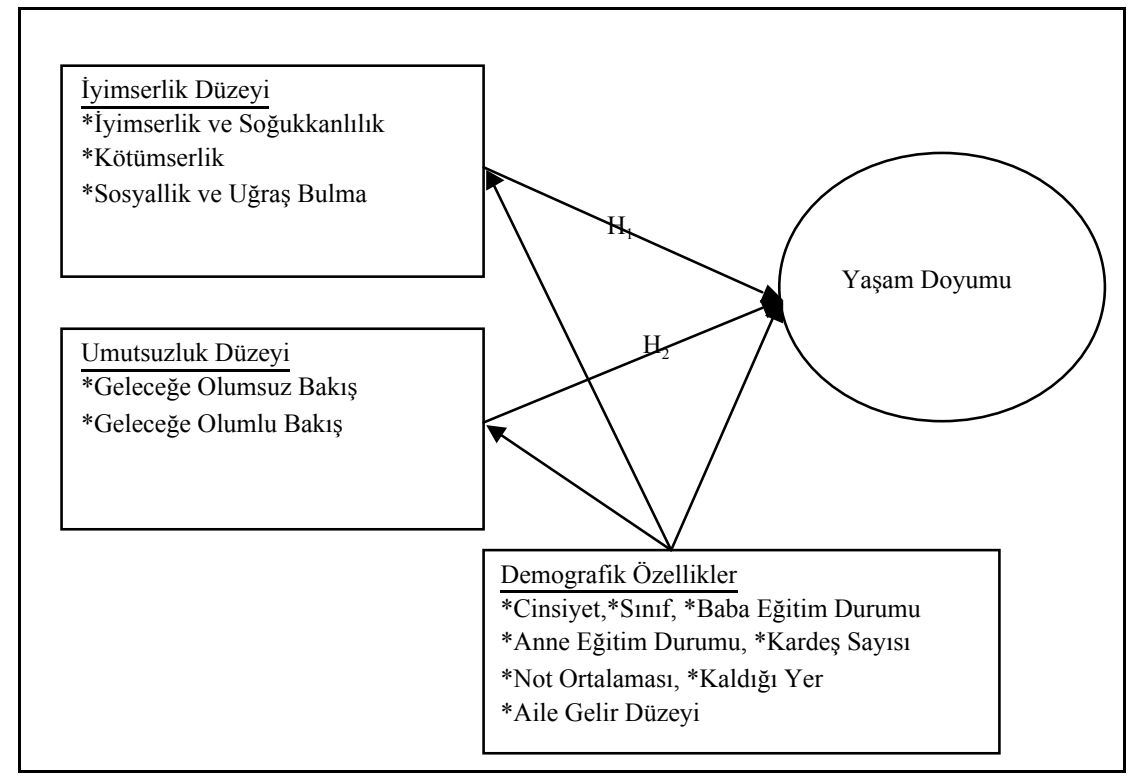

Şekil 1. Araştırma Modeli

\section{Hipotezler}

$\mathrm{H}_{0}$ : İyimserlik düzeyinin yaşam doyumu üzerine anlamlı bir etkisi yoktur.

$\mathrm{H}_{1}$ : İyimserlik düzeyinin yaşam doyumu üzerine anlamlı bir etkisi vardır.

$\mathrm{H}_{1 \mathrm{a}}$ : İyimserlik ve Soğukkanlllık düzeyinin yaşam doyumu üzerine anlamlı bir etkisi vardir.

$\mathrm{H}_{2 \mathrm{a}}$ : Kötümserlik düzeyinin yaşam doyumu üzerine anlamlı bir etkisi vardır.

$\mathrm{H}_{3 \mathrm{a}}$ : Sosyallik ve Uğraş Bulma düzeyinin yaşam doyumu üzerine anlamlı bir etkisi vardır.

$\mathrm{H}_{0}$ : Umutsuzluk düzeyinin yaşam doyumu üzerine anlamlı bir etkisi yoktur.

$\mathrm{H}_{2}$ : Umutsuzluk düzeyinin yaşam doyumu üzerine anlamlı bir etkisi vardır.

$\mathrm{H}_{2 \mathrm{a}}$ : Geleceğe Olumsuz Bakış düzeyinin yaşam doyumu üzerine anlamlı bir etkisi vardır.

$\mathrm{H}_{2 \mathrm{~b}}$ : Geleceğe Olumlu Bakış düzeyinin yaşam doyumu üzerine anlamlı bir etkisi vardır.

\section{Veri Analizi ve Bulgular}

Araştırmada veri analizi için Statistical Package for Social Sciences (SPSS) 21 paket programı kullanılmıştır. Araştırmada öncelikle katılımcıların sosyodemografik özelliklerine ilişkin frekans analizi yapılmıştır. Daha sonra iyimserlik, umutsuzluk ve yaşam doyumu ölçekleri için faktör analizi ve güvenirlik testleri yapılmıştır. Faktör analizi sonucu iyimserlik ölçeği için üç alt boyut, umutsuzluk ölçeği için iki alt boyut ve yaşam doyumu ölçeği için tek boyut bulunmuştur. Değişkenler ve alt boyutlarına ilişkin Kolmogorov-smirnov normallik testi yapılmıştır. Dağılımın normal olmadığına karar verilerek değişkenlerin sosyo-demografik özelliklere göre farklılık gösterip göstermediğini belirlemek için nonparametrik testler yapılmıştır. Nonparamterik testler olarak Mann Whitney U ve Kruskal Wallis testleri yapılmıştır. Bunun sonrasında iyimserlik düzeyinin yaşam doyumuna etkisine ilişkin çoklu regresyon testi yapılmıştır. Umutsuzluk düzeyinin yaşam doyumu üzerine etkisine yönelik çoklu regresyon testi yapılmıştır. Bu kapsamda birer çoklu regresyon modeli test edilmiştir. Değişkenler ve alt boyutları arasındaki ilişkileri belirlemeye yönelik korelasyon analizleri de yapılmıştır. 


\section{Katılımcıların Sosyo-Demografik Özelliklerine}

\section{Yönelik Frekans Analizi}

Aşağıda tablo 1'de öğrencilerin sosyo-demografik özelliklerine ilişkin frekans dağılımları ifade edil-

mektedir.

Tablo 1. Öğrencilerin Sosyo-Demografik Özelliklerine Yönelik Frekans Analizi

\begin{tabular}{|c|c|c|c|}
\hline Değişken & Gruplar & Frekans & Yüzde \\
\hline \multirow[t]{3}{*}{ Cinsiyet } & Erkek & 394 & 38,6 \\
\hline & $\mathrm{K} 1 \mathrm{Z}$ & 628 & 61,4 \\
\hline & Toplam & 1022 & 100 \\
\hline \multirow[t]{5}{*}{$\begin{array}{l}\text { Sinif } \\
\end{array}$} & 9. $\sin 1 f$ & 316 & 30,9 \\
\hline & $10 . \sin 1 f$ & 254 & 24,9 \\
\hline & 11. sinif & 224 & 21,9 \\
\hline & 12. sinif & 228 & 22,3 \\
\hline & Toplam & 1022 & 100 \\
\hline \multirow[t]{7}{*}{ Baba Eğitim Durumu } & Okuryazar Değil & 15 & 1,5 \\
\hline & Ilk-Orta & 336 & 32,9 \\
\hline & Lise & 450 & 44 \\
\hline & Yüksekokul & 55 & 5,4 \\
\hline & Üniversite & 145 & 14,2 \\
\hline & Yüksek Lisans & 21 & 2,1 \\
\hline & Toplam & 1022 & 100 \\
\hline \multirow[t]{7}{*}{ Anne Eğitim Durumu } & Okuryazar Değil & 22 & 2,2 \\
\hline & İlk-Orta & 491 & 48 \\
\hline & Lise & 377 & 36,9 \\
\hline & Yüksekokul & 27 & 2,6 \\
\hline & Üniversite & 92 & 9 \\
\hline & Yüksek Lisans & 13 & 1,3 \\
\hline & Toplam & 1022 & 100 \\
\hline \multirow[t]{5}{*}{ Kardeş Say1S1 } & 1 kardeş & 187 & 18,3 \\
\hline & 2 kardeş & 668 & 65,4 \\
\hline & 3 kardeş & 123 & 12 \\
\hline & 4 ve üzeri kardeş & 44 & 4,3 \\
\hline & Toplam & 1022 & 100 \\
\hline \multirow[t]{6}{*}{ Not Ortalaması } & Çok Düşük & 44 & 4,3 \\
\hline & Düşük & 163 & 15,9 \\
\hline & Orta & 591 & 57,8 \\
\hline & Yüksek & 202 & 19,8 \\
\hline & Çok Yüksek & 22 & 2,2 \\
\hline & Toplam & 1022 & 100 \\
\hline \multirow[t]{5}{*}{ Kaldığı Yer } & Aile Yanında & 993 & 97,2 \\
\hline & Yurtta & 10 & 1 \\
\hline & Akraba Yanında & 10 & 1 \\
\hline & Arkadaşlarıyla Birlikte & 9 & 0,9 \\
\hline & Toplam & 1022 & 100 \\
\hline \multirow[t]{4}{*}{ Aile Gelir Düzeyi } & Düşük & 46 & 4,5 \\
\hline & Orta & 891 & 87,2 \\
\hline & Yüksek & 85 & 8,3 \\
\hline & Toplam & 1022 & 100 \\
\hline
\end{tabular}




\section{Değişkenlerin Faktör Analizi ve Güvenirlik Testi Sonuçları}

Araştırmada kullanılan iyimserlik ölçeği, umutsuzluk ölçeği ve yaşam doyumu ölçeği için faktör analizi ve güvenirlik testleri yapılmıştır. İyimserlik ölçeğine fak- tör analizi uygulanması sonucu üç alt boyut, umutsuzluk ölçeğine faktör analizi uygulanması sonucu iki alt boyut ve yaşam doyumu ölçeğine faktör analizi uygulanması sonucu tek alt boyut bulunmuștur.

Tablo 2. İyimserlik Ölçeği Faktör Analizi ve Güvenirlik Testi Sonuçları

\begin{tabular}{|c|c|c|c|c|c|}
\hline & Sorular & $\begin{array}{c}\text { Faktör } \\
\text { Ağırlıkları }\end{array}$ & $\begin{array}{c}\text { Faktörün } \\
\text { Açıklayıcılığ1 } \\
(\%)\end{array}$ & $\begin{array}{c}\text { Başlangıç } \\
\text { Özdeğerleri }\end{array}$ & $\begin{array}{c}\text { Cronbach's } \\
\text { Alpha }\end{array}$ \\
\hline \multirow{6}{*}{$\begin{array}{l}\text { İyimserlik ve } \\
\text { Soğukkanlılık }\end{array}$} & i11 & ,691 & \multirow[t]{6}{*}{20,933} & \multirow[t]{6}{*}{3,264} & \multirow[t]{6}{*}{0,73} \\
\hline & i4 & ,684 & & & \\
\hline & $\mathrm{i} 2$ & ,637 & & & \\
\hline & i5 & ,617 & & & \\
\hline & i10 & 601 & & & \\
\hline & i1 & 601 & & & \\
\hline \multirow[t]{4}{*}{ Kötümserlik } & i9 & 833 & \multirow[t]{4}{*}{20,382} & \multirow[t]{4}{*}{1,868} & \multirow[t]{4}{*}{0,77} \\
\hline & i12 &, 790 & & & \\
\hline & i8 &, 785 & & & \\
\hline & i3 &, 615 & & & \\
\hline \multirow{2}{*}{$\begin{array}{l}\text { Sosyallik ve Uğraş } \\
\text { Bulma }\end{array}$} & i6 &, 835 & \multirow[t]{2}{*}{13,297} & \multirow[t]{2}{*}{1,422} & \multirow[t]{2}{*}{0,71} \\
\hline & i7 &, 832 & & & \\
\hline
\end{tabular}

Tablo 2'de iyimserlik ölçeği için KMO değerinin 0,780 ve Bartlett's testi sonucunun $0,000<0,05$ olduğu görülmektedir. Bulunan bu değerler veri setinin faktör analizi için uygun olduğunu göstermektedir. İyimserlik ölçeğine faktör analizi uygulanmış ve literatürle uyumlu üç alt boyut elde edilmiştir. Bu kapsamda faktör 1 "İyimserlik ve Soğukkanlllık", faktör 2 "Kötümserlik" ve faktör 3 "Sosyallik ve Uğraş Bulma" olarak isimlendirilmiştir. Faktör 1 toplam varyansın $\% 20,993$ 'ünü, faktör 2 toplam varyansın \%20,382'sini, faktör 3 ise toplam varyansın \%13,297'sini açıklamaktadır. Bu üç faktör toplam varyansın \%54,611'ini açıklamaktadır. Başlangıç özdeğerlerinin (Initial Eigenvalues) faktör 1 için 3,264, faktör 2 için 1,868 ve faktör 3 için 1,422 olduğu gözlenmiştir. Güvenirlik testi sonuçlarına göre cronbach's alpha değeri faktör 1 için 0,73 olarak, faktör 2 için 0,77 olarak ve faktör 3 için 0,71 olarak belirlenmiştir.
Tablo 3'te umutsuzluk ölçeği için KMO değerinin 0,928 ve Bartlett's testi sonucunun $0,000<0,05$ olduğu gözlenmiştir. Bulunan bu değerlere göre veri seti faktör analizi için uygundur. Umutsuzluk ölçeğine faktör analizi uygulanması neticesinde iki alt boyut ortaya çıkmıştır. Bu boyutlardan faktör 1 "Geleceğe Olumsuz Bakış", faktör 2 ise "Geleceğe Olumlu Bakış" olarak isimlendirilmiştir. Faktör 1 toplam varyansin \%24,452'sini, faktör 2 ise toplam varyansin \%19,885'ini açıklamaktadır. Bulunan iki faktör toplam varyansın \%44,337’sini açıklamaktadır. Başlangıç özdeğerlerinin faktör 1 için 6,5 ve faktör 2 için 2,367 olduğu gözlenmiştir. Güvenirlik testi sonucu bulunan cronbach's alpha değerleri faktör 1 için 0,87 iken faktör 2 için ise 0,82 'dir. 
Tablo 3. Umutsuzluk Ölçeği Faktör Analizi ve Güvenirlik Testi Sonuçları

\begin{tabular}{|c|c|c|c|c|c|}
\hline & Sorular & $\begin{array}{c}\text { Faktör } \\
\text { Ağırlıkla } \\
\text { r1 }\end{array}$ & $\begin{array}{c}\text { Faktörün } \\
\text { Açıklayıcıllı̆g } 1 \\
(\%)\end{array}$ & $\begin{array}{c}\text { Başlangıç } \\
\text { Özdeğerleri }\end{array}$ & Cronbach's Alpha \\
\hline \multirow{11}{*}{$\begin{array}{l}\text { Geleceğe Olumsuz } \\
\text { Bakış }\end{array}$} & u18 &, 740 & \multirow[t]{11}{*}{24,452} & \multirow[t]{11}{*}{6,500} & \multirow[t]{11}{*}{0,87} \\
\hline & u11 &, 721 & & & \\
\hline & u16 & ,711 & & & \\
\hline & u9 & ,698 & & & \\
\hline & $\mathrm{u} 20$ &, 692 & & & \\
\hline & u17 & ,691 & & & \\
\hline & $\mathrm{u} 7$ & ,678 & & & \\
\hline & $\mathrm{u} 2$ & ,639 & & & \\
\hline & u14 &, 592 & & & \\
\hline & $\mathrm{u} 4$ & 451 & & & \\
\hline & u12 & 429 & & & \\
\hline \multirow[t]{9}{*}{ Geleceğe Olumlu Bakış } & u15 &, 741 & \multirow[t]{9}{*}{19,885} & \multirow[t]{9}{*}{2,367} & \multirow[t]{9}{*}{0,82} \\
\hline & u19 &, 737 & & & \\
\hline & $\mathrm{u} 1$ &, 686 & & & \\
\hline & u13 & 656 & & & \\
\hline & $\mathrm{u} 6$ & ,641 & & & \\
\hline & u3 &, 575 & & & \\
\hline & $\mathrm{u} 10$ &, 557 & & & \\
\hline & $\mathrm{u} 5$ &, 519 & & & \\
\hline & $\mathrm{u} 8$ & 470 & & & \\
\hline
\end{tabular}

Tablo 4. Yaşam Doyumu Ölçeği Faktör Analizi ve Güvenirlik Testi Sonuçları

\begin{tabular}{|c|c|c|c|c|c|}
\hline & Sorular & $\begin{array}{c}\text { Faktör } \\
\text { Ağırlıkları }\end{array}$ & $\begin{array}{c}\text { Faktörün } \\
\text { Açıklayıcıllı̆ı } \\
(\%)\end{array}$ & $\begin{array}{c}\text { Başlangıç } \\
\text { Özdeğerleri }\end{array}$ & $\begin{array}{c}\text { Cronbach's } \\
\text { Alpha }\end{array}$ \\
\hline \multirow[t]{5}{*}{ Yaşam Doyumu } & $\mathrm{y} 3$ & 816 & \multirow[t]{5}{*}{58,996} & \multirow[t]{5}{*}{2,950} & \multirow[t]{5}{*}{0,820} \\
\hline & $\mathrm{y} 2$ &, 794 & & & \\
\hline & $\mathrm{y} 4$ &, 780 & & & \\
\hline & y1 &, 777 & & & \\
\hline & $\mathrm{y} 5$ & ,663 & & & \\
\hline
\end{tabular}

Tablo 4'te görüldüğ̈̈ gibi Yaşam Doyumu ölçeği için KMO değeri 0,836 ve Bartlett's testi sonucu $0,000<0,05$ olarak bulunmuştur. Bulunan sonuçlar veri setinin faktör analizi için uygun olduğunu göstermektedir. Faktör analizi sonucu bulunan tek boyut toplam varyansın \%58,996'sını açıklamaktadır. Başlangıç özdeğerlerinin bulunan boyut için 2,950 olduğu gözlenmiştir. Yaşam doyumu boyutu için cronbach's alpha değerinin 0,820 olduğu gözlenmiştir.

\section{Değişkenlerin Sosyo-demografik Özelliklere Göre Farklılıkları}

Araştırma değişkenleri olan iyimserlik, umutsuzluk, yaşam doyumu ölçekleri ve alt boyutlarının normal dağılım gösterip göstermediği Kolmogorov-Smirnov normallik testi ile sınanmıştır. Bulunan sonuca göre değişkenlerin sosyo-demografik özelliklere göre farklılıklarının incelenmesinde parametrik veya nonparametrik testlerin kullanılacağı belirlenecektir. 
Tablo 5. Kolmogorov Smirnov Normallik Testi Sonuçları

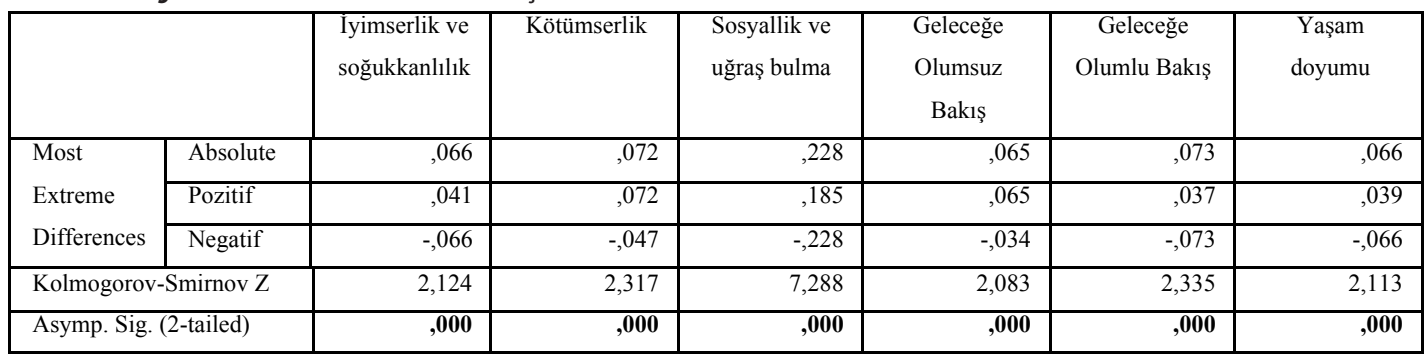

$\mathrm{H}_{0}=$ İyimserlik ölçeği alt boyutları normal dağılım göstermektedir.

$\mathrm{H}_{1}=$ İyimserlik ölçeği alt boyutları normal dağılım göstermemektedir.

$\mathrm{H}_{0}$ : Umutsuzluk ölçeği alt boyutları normal dağılım göstermektedir.

$\mathrm{H}_{2}=$ Umutsuzluk ölçeği alt boyutları normal dağılım göstermemektedir.

$\mathrm{H}_{0}$ : Yaşam doyumu ölçeği normal dağılım göstermektedir.

$\mathrm{H}_{3}$ : Yaşam doyumu ölçeği normal dağılım göstermemektedir.

Tablo 5’e bakıldığında $\mathrm{p}<0,05$ olduğundan her üç değişken için de $\mathrm{H}_{0}$ hipotezleri reddedilmiştir. Değişkenler normal dağılım göstermemektedir. Bu nedenle nonparametrik testler uygulanmıştır. Nonparametrik testler olarak Mann Whitney U ve Kruskal Wallis testleri uygulanmıștır.

Değişkenlerin sosyo-demografik özelliklere göre farklılıklarını belirlemek için nonparametrik testler olan Mann Whitney U ve Kruskal Wallis uygulanmıştır. Değişkenlerin cinsiyete göre bir farklılık gösterip göstermediğini belirlemek için Mann Whitney U testi uygulanmıştır. Değişkenlerin sınıf, baba eğitim durumu, anne eğitim durumu, kardeş sayısı, not ortalaması, kaldığ $\breve{1}_{1}$ yer ve aile gelir düzeyine göre bir farklılık gösterip göstermediğini belirlemek için Kruskal Wallis testleri yapılmıştır.

İyimserlik ve soğukkanlılık boyutunun cinsiyete göre farklılık gösterdiği belirlenmiştir $(\mathrm{p}<0,05)$. Buna göre iyimserlik ve soğukkanlılık boyutu sıra ortalamaları- na bakıldığında erkek öğrencilerin ortalamalarının (556,79), kız öğrencilerin ortalamalarından $(483,09)$ yüksek olduğu gözlenmiştir. Bu kapsamda erkek öğrencilerin kızlara göre iyimserlik ve soğukkanlılık düzeylerinin daha yüksek olduğu söylenebilir. İyimserlik ve soğukkanlılık boyutu not ortalamasına göre farklılık göstermektedir $(\mathrm{p}<0,05)$. İyimserlik ve soğukkanlılık boyutu sıra ortalamalarına bakıldığında, not ortalaması çok yüksek olanların ortalamaları $(570,64)$ diğerlerinden fazladır. Buna göre not ortalaması çok yüksek olanların iyimserlik ve soğukkanlılık düzeyleri diğerlerinden fazladır.

Kötümserlik boyutunun cinsiyete göre farklılık gösterdiği gözlenmiştir $(\mathrm{p}<0,05)$. Kötümserlik boyutu sıra ortalamalarına bakıldığında kız öğrencilerin ortalamalarının $(530,35)$, erkek öğrencilerin ortalamalarından $(481,46)$ yüksek olduğu görülmektedir. Buna göre kız öğrencilerin erkek öğrencilere göre kötümserlik düzeylerinin daha yüksek olduğu ifade edilebilir. Kötümserlik boyutunun sınıf düzeyine göre farklılık gösterdiği gözlenmiştir $(\mathrm{p}<0,05)$. Kötümserlik boyutunun sıra ortalamalarına bakıldığında 10.s1nıfların ortalamalarının $(552,95)$ diğer sinıflardan yüksek olduğu görülmektedir. Buna göre 10. sinıfların diğerlerine göre kötümserlik düzeylerinin daha yüksek olduğu söylenebilir. Kötümserlik boyutu not ortalamasına göre farklılık göstermektedir $(\mathrm{p}<0,05)$. Buna göre not ortalaması düşük olanların kötümserlik boyutu ortalamaları $(593,72)$ diğerlerinden fazladır. Not ortalaması düşük olanların kötümserlik düzeylerinin diğerlerinden fazla olduğu söylenebilir. Kötümserlik boyutu öğrencilerin kaldığı yere göre farklılık göstermektedir $(\mathrm{p}<0,05)$. Akrabasının yanında kalan öğrencilerin kötümserlik boyutu ortalamaları $(791,55)$ diğerlerinden yüksektir. Buna göre akrabasının yanında kalan öğrencilerin kötümserlik düzeylerinin diğerlerinden yüksek olduğu söylenebilir. 
Tablo 6. Değişkenlerin Sosyo-demografik Özelliklere Göre Farklılıklarının Testi

\begin{tabular}{|c|c|c|c|}
\hline Grup & Değișkenler & Test & $\mathbf{p}$ \\
\hline \multirow[t]{6}{*}{ Cinsiyet } & İyimserlik ve Soğukkanlılık & Mann Whitney U & 0,000 \\
\hline & Kötümserlik & Mann Whitney U & $\mathbf{0 , 0 1 0}$ \\
\hline & Sosyallik ve Uğraş Bulma & Mann Whitney U & 0,130 \\
\hline & Geleceğe Olumsuz Bakış & Mann Whitney U & 0,099 \\
\hline & Geleceğe Olumlu Bakış & Mann Whitney U & 0,388 \\
\hline & Yaşam Doyumu & Mann Whitney U & 0,067 \\
\hline \multirow[t]{6}{*}{ Sinıf } & İyimserlik ve Soğukkanlılık & Kruskal Wallis & 0,960 \\
\hline & Kötümserlik & Kruskal Wallis & 0,040 \\
\hline & Sosyallik ve Uğraş Bulma & Kruskal Wallis & 0,014 \\
\hline & Geleceğe Olumsuz Bakış & Kruskal Wallis & 0,597 \\
\hline & Geleceğe Olumlu Bakış & Kruskal Wallis & 0,001 \\
\hline & Yaşam Doyumu & Kruskal Wallis & 0,015 \\
\hline \multirow{6}{*}{$\begin{array}{l}\text { Baba Eğitim } \\
\text { Durumu }\end{array}$} & İyimserlik ve Soğukkanlılık & Kruskal Wallis & 0,638 \\
\hline & Kötümserlik & Kruskal Wallis & 0,381 \\
\hline & Sosyallik ve Uğraş Bulma & Kruskal Wallis & 0,192 \\
\hline & Geleceğe Olumsuz Bakış & Kruskal Wallis & 0,117 \\
\hline & Geleceğe Olumlu Bakış & Kruskal Wallis & 0,193 \\
\hline & Yaşam Doyumu & Kruskal Wallis & 0,006 \\
\hline \multirow{6}{*}{$\begin{array}{l}\text { Anne Eğitim } \\
\text { Durumu }\end{array}$} & İyimserlik ve Soğukkanlılık & Kruskal Wallis & 0,531 \\
\hline & Kötümserlik & Kruskal Wallis & 0,161 \\
\hline & Sosyallik ve Uğraş Bulma & Kruskal Wallis & 0,016 \\
\hline & Geleceğe Olumsuz Bakış & Kruskal Wallis & 0,006 \\
\hline & Geleceğe Olumlu Bakış & Kruskal Wallis & 0,084 \\
\hline & Yaşam Doyumu & Kruskal Wallis & 0,853 \\
\hline \multirow[t]{6}{*}{ Kardeş Sayısı } & İyimserlik ve Soğukkanlılık & Kruskal Wallis & 0,064 \\
\hline & Kötümserlik & Kruskal Wallis & 0,102 \\
\hline & Sosyallik ve Uğraş Bulma & Kruskal Wallis & 0,126 \\
\hline & Geleceğe Olumsuz Bakış & Kruskal Wallis & 0,182 \\
\hline & Geleceğe Olumlu Bakıș & Kruskal Wallis & 0,445 \\
\hline & Yaşam Doyumu & Kruskal Wallis & 0,128 \\
\hline \multirow[t]{6}{*}{ Not Ortalaması } & İyimserlik ve Soğukkanlılık & Kruskal Wallis & $\mathbf{0 , 0 2 0}$ \\
\hline & Kötümserlik & Kruskal Wallis & 0,001 \\
\hline & Sosyallik ve Uğraş Bulma & Kruskal Wallis & 0,229 \\
\hline & Geleceğe Olumsuz Bakış & Kruskal Wallis & 0,000 \\
\hline & Geleceğe Olumlu Bakış & Kruskal Wallis & 0,000 \\
\hline & Yaşam Doyumu & Kruskal Wallis & 0,000 \\
\hline \multirow[t]{6}{*}{ Kaldığı Yer } & İyimserlik ve Soğukkanlılık & Kruskal Wallis & 0,618 \\
\hline & Kötümserlik & Kruskal Wallis & 0,020 \\
\hline & Sosyallik ve Uğraş Bulma & Kruskal Wallis & 0,003 \\
\hline & Geleceğe Olumsuz Bakış & Kruskal Wallis & 0,002 \\
\hline & Geleceğe Olumlu Bakış & Kruskal Wallis & 0,080 \\
\hline & Yaşam Doyumu & Kruskal Wallis & $\mathbf{0 , 0 2 0}$ \\
\hline \multirow[t]{6}{*}{ Aile Gelir Düzeyi } & İyimserlik ve Soğukkanlılık & Kruskal Wallis & 0,088 \\
\hline & Kötümserlik & Kruskal Wallis & $\mathbf{0 , 0 3 7}$ \\
\hline & Sosyallik ve Uğraş Bulma & Kruskal Wallis & 0,151 \\
\hline & Geleceğe Olumsuz Bakıș & Kruskal Wallis & 0,049 \\
\hline & Geleceğe Olumlu Bakıș & Kruskal Wallis & 0,083 \\
\hline & Yaşam Doyumu & Kruskal Wallis & 0,000 \\
\hline
\end{tabular}

Kötümserlik boyutu öğrencilerin aile gelir düzeyine göre farklılık göstermektedir $(\mathrm{p}<0,05)$. Aile gelir düzeyi düşük olan öğrencilerin kötümserlik boyutu ortalamaları $(597,63)$ diğerlerinden fazladır. Buna göre aile gelir düzeyi düşük olan öğrencilerin kötümserlik düzeyleri diğerlerinden fazladır.
Sosyallik ve uğraş bulma boyutu sınıf düzeyine göre farklılık göstermektedir $(\mathrm{p}<0,05)$. Sosyallik ve uğraş bulma boyutu sıra ortalamalarına bakıldığında 12. sınıfların ortalamalarının $(548,60)$ diğerlerinden yüksek olduğu gözlenmiştir. Buna göre 12. sınıfların sosyallik ve uğraş bulma düzeylerinin diğerlerinden 
yüksek olduğu söylenebilir. Sosyallik ve uğraş bulma boyutu anne eğitim durumuna göre farklılık göstermektedir $(p<0,05)$. Sosyallik ve uğraş bulma boyutu sıra ortalamalarına bakıldığında, anne eğitim durumu lise olanların ortalamalarının $(549,34)$ diğerlerinden yüksek olduğu görülmektedir. Buna göre anne eğitim durumu lise olanların sosyallik ve uğraş bulma düzeylerinin diğerlerinden yüksek olduğu söylenebilir. Sosyallik ve uğraş bulma boyutu öğrencilerin kaldığı yere göre farklılık göstermektedir $(p<0,05)$. Ailesinin yanında kalan öğrencilerin sosyallik ve uğraş bulma boyutu ortalamaları $(516,90)$ diğerlerinden yüksektir. Ailesinin yanında kalan öğrencilerin sosyallik ve uğraş bulma düzeylerinin diğerlerinden yüksek olduğu söylenebilir.

Geleceğe olumsuz bakış boyutunun anne eğitim durumuna göre farklılık gösterdiği belirlenmiştir $(\mathrm{p}<0,05)$. Geleceğe olumsuz bakış düzeyi sıra ortalamalarına bakıldığında, anne eğitim durumu yüksek lisans olanların ortalamalarının $(672,62)$ diğerlerinden yüksek olduğu gözlenmiştir. Buna göre anne eğitim durumu yüksek lisans olanların geleceğe olumsuz bakış düzeylerinin diğerlerinden yüksek olduğu söylenebilir. Geleceğe olumsuz bakış boyutu not ortalamasına göre farklılık göstermektedir $(\mathrm{p}<0,05)$. Buna göre not ortalaması çok düşük olanların geleceğe olumsuz bakış boyutu ortalamaları $(616,42)$ diğerlerinden fazladır. Not ortalaması çok düşük olanların geleceğe olumsuz bakış düzeylerinin diğerlerinden fazla olduğu söylenebilir. Geleceğe olumsuz bakış boyutu öğrencilerin kaldığı yere göre farklılık göstermektedir $(\mathrm{p}<0,05)$. Arkadaşlarıyla birlikte kalan öğrencilerin geleceğe olumsuz bakış ortalamaları $(815,72)$ diğerlerinden yüksektir. Bu kapsamda arkadaşlarıyla birlikte kalan öğrencilerin geleceğe olumsuz bakış düzeylerinin diğerlerinden yüksek olduğu söylenebilir. Geleceğe olumsuz bakış boyutu öğrencilerin aile gelir düzeyine göre farklılık göstermektedir( $\mathrm{p}<0,05)$. Aile gelir düzeyi düşük olan öğrencilerin geleceğe olumsuz bakış boyutu ortalamaları $(570,84)$ diğerlerinden fazladır. Bu kapsamda aile gelir düzeyi düşük olan öğrencilerin geleceğe olumsuz bakış düzeyleri diğerlerinden fazladır.

Geleceğe olumlu bakış boyutu sınıf düzeyine göre farklılık göstermektedir $(\mathrm{p}<0,05)$. Geleceğe olumlu bakış boyutu sıra ortalamalarına bakıldığında 12 . sınıfların ortalamalarının $(563,56)$ diğerlerinden yüksek olduğu görülmektedir. Buna göre 12. sınıfla- rın geleceğe olumlu bakış düzeylerinin diğer sınıflara göre daha yüksek olduğu söylenebilir. Geleceğe olumlu bakış boyutu not ortalamasına göre farklılık göstermektedir $(\mathrm{p}<0,05)$. Not ortalaması çok yüksek olanların ortalamaları $(598,20)$ diğerlerinden fazladır. Buna göre not ortalaması çok yüksek olanların geleceğe olumlu bakış düzeyleri diğerlerinden fazladir.

Yaşam doyumunun sınıf düzeyine göre farklılık gösterdiği belirlenmiştir $(\mathrm{p}<0,05)$. Yaşam doyumu sıra ortalamalarına bakıldığında 9.sınıfların ortalamalarının $(545,71)$ diğer sınıfların ortalamalarından yüksek olduğu gözlenmiştir. Buna göre 9.sınıfların yaşam doyumu düzeylerinin diğerlerinden yüksek olduğu söylenebilir. Yaşam doyumu baba eğitim durumuna göre farklılık göstermektedir $(\mathrm{p}<0,05)$. Yaşam doyumu sıra ortalamalarına bakıldığında, baba eğitim durumu lise olanların ortalamalarının $(547,33)$ diğerlerinden yüksek olduğu görülmektedir. Buna göre baba eğitim durumu lise olanların yaşam doyumlarının diğerlerinden yüksek olduğu söylenebilir. Yaşam doyumu not ortalamasına göre farklılık göstermektedir $(\mathrm{p}<0,05)$. Yaşam doyumu sıra ortalamalarına bakıldığında, not ortalaması çok yüksek olanların ortalamaları $(653,36)$ diğerlerinden fazladır. Buna göre not ortalaması çok yüksek olanların yaşam doyum düzeylerinin diğerlerinden fazla olduğu ifade edilebilir. Yaşam doyumu öğrencilerin kaldığı yere göre farklılık göstermektedir $(\mathrm{p}<0,05)$. Arkadaşlarıyla birlikte kalan öğrencilerin yaşam doyumu ortalamaları $(694,67)$ diğerlerinden yüksektir. Buna göre arkadaşlarıyla birlikte kalan öğrencilerin yaşam doyumlarının daha yüksek olduğu söylenebilir. Yaşam doyumu öğrencilerin aile gelir düzeyine göre farkll1ı göstermektedir $(\mathrm{p}<0,05)$. Aile gelir düzeyi yüksek olan öğrencilerin yaşam doyumu ortalamaları $(639,59)$ diğerlerinden yüksektir. Buna göre aile gelir düzeyi yüksek olan öğrencilerin yaşam doyumlarının diğerlerinden yüksek olduğu söylenebilir.

\section{Çoklu Regresyon Testleri}

İyimserlik ve umutsuzluk düzeyinin yaşam doyumu üzerine etkisi araştırılmaktadır. Bu kapsamda iki ayrı çoklu regresyon modeli test edilmiştir. Buna göre ilk olarak iyimserlik düzeyinin yaşam doyumu üzerine etkisi bir çoklu regresyon modeli ile test edilmiştir. İkinci olarak ise umutsuzluk düzeyinin yaşam doyumu üzerine etkisi bir çoklu regresyon modeli ile test edilmiştir. 


\section{İyimserlik Düzeyinin Yaşam Doyumu Üzerine Etkisi}

İyimserlik düzeyinin yaşam doyumu üzerine etkisine ilişkin bir çoklu regresyon modeli test edilmiştir. İyimserlik düzeyi bağımsız değişken olarak, yaşam doyumu ise bağımlı değişken olarak ele alınmıştır. $\mathrm{Bu}$ kapsamda aşağıdaki hipotezler test edilmiştir.

$\mathrm{H}_{0}$ : İyimserlik düzeyinin yaşam doyumu üzerine anlamlı bir etkisi yoktur.
$\mathrm{H}_{1}$ : İyimserlik düzeyinin yaşam doyumu üzerine anlamlı bir etkisi vardır.

$\mathrm{H}_{1 \mathrm{a}}$ : İyimserlik ve Soğukkanlılık düzeyinin yaşam doyumu üzerine anlamlı bir etkisi vardır.

$\mathrm{H}_{2 \mathrm{a}}$ : Kötümserlik düzeyinin yaşam doyumu üzerine anlamlı bir etkisi vardır.

$\mathrm{H}_{3 \mathrm{a}}$ : Sosyallik ve Uğraş Bulma düzeyinin yaşam doyumu üzerine anlamlı bir etkisi vardır.

Tablo 7. İyimserlik Düzeyinin Yaşam Doyumu Üzerine Etkisine Illişkin Çoklu Regresyon Modeli Sonuçları

\begin{tabular}{|c|c|c|c|c|c|}
\hline \multirow[t]{2}{*}{ Model } & \multicolumn{2}{|c|}{$\begin{array}{c}\text { Standardize Edilmemiş } \\
\text { Katsayılar }\end{array}$} & \multirow{2}{*}{$\begin{array}{c}\text { Standardize } \\
\text { Edilmiş } \\
\text { Katsayılar } \\
\text { Beta }\end{array}$} & \multirow[t]{2}{*}{$\mathrm{t}$} & \multirow[t]{2}{*}{ Sig. } \\
\hline & $\mathrm{B}$ & Std. Hata & & & \\
\hline (Sabit) & 1,966 &, 182 & & 10,798 &, 000 \\
\hline İyimserlik ve soğukkanlılık &, 395 &, 034 &, 344 & 11,574 &, 000 \\
\hline Kötümserlik &,- 160 &, 028 &,- 167 & $-5,716$ &, 000 \\
\hline Sosyallik ve uğraş bulma &, 099 & ,029 &, 096 & 3,377 &, 001 \\
\hline
\end{tabular}

Tablo 7'de görüldüğü gibi $\mathrm{p}<0,05$ olduğundan $\mathrm{H}_{1 \mathrm{a}}, \mathrm{H}_{2 \mathrm{a}}$ ve $\mathrm{H}_{3 \mathrm{a}}$ desteklenmiştir. İyimserlik ve soğukkanlılık düzeyinin yaşam doyumu üzerine pozitif yönlü anlamlı bir etkisi $(\beta=0,344)$ vardır $(\mathrm{p}<0,05)$. Bu kapsamda iyimserlik ve soğukkanlılığın yaşam doyumunu arttırdığı söylenebilir. İyimserlik ve soğukkanlılık düzeyi arttıkça yaşam doyumu da artmaktadır. Kötümserlik düzeyinin yaşam doyumu üzerine negatif yönlü anlamlı bir etkisi $(\beta=-0,167)$ mevcuttur $(\mathrm{p}<0,05)$. Öğrencilerin kötümserlik düzeyine sahip olması yaşam doyumlarını azaltmaktadır. Bu çerçevede kötümserlik düzeyi arttıkça yaşam doyumunun azaldığ söylenebilir. Sosyallik ve uğraş bulma düzeyinin yaşam doyumu üzerine pozitif yönlü anlamlı bir etkisi $(\beta=0,096) \operatorname{vardır}(p<0,05)$. Diğer bir deyişle sosyallik ve uğraş bulma düzeyi arttıkça yaşam doyumu da artmaktadır. Öğrencilerin sosyallik ve uğraş bulma düzeylerinin yaşam doyumlarını arttırdığı söylenebilir. Ancak katsayı düzeyi yani etkisi diğerlerine nazaran düşük düzeydedir. Çoklu regresyon modeline göre beta değerlerine bakıldığında iyimserlik ve soğukkanlılık düzeyinin yaşam doyumu üzerinde daha etkili olduğu söylenebilir.

\section{Umutsuzluk Düzeyinin Yaşam Doyumu Üzerine Etkisi}

Umutsuzluk düzeyinin yaşam doyumu üzerine etkisine ilişkin bir çoklu regresyon modeli test edilmiştir. Umutsuzluk düzeyi bağımsız değişken olarak ele alınırken, yaşam doyumu ise bağımlı değişken olarak incelenmiştir. Bu çerçevede aşağıdaki hipotezler test edilmiştir.

$\mathrm{H}_{0}$ : Umutsuzluk düzeyinin yaşam doyumu üzerine anlamlı bir etkisi yoktur.

$\mathrm{H}_{2}$ : Umutsuzluk düzeyinin yaşam doyumu üzerine anlamlı bir etkisi vardır.

$\mathrm{H}_{2 \mathrm{a}}$ : Geleceğe olumsuz bakış düzeyinin yaşam doyumu üzerine anlamlı bir etkisi vardır.

$\mathrm{H}_{2 \mathrm{~b}}$ : Geleceğe olumlu bakış düzeyinin yaşam doyumu üzerine anlamlı bir etkisi vardır. 
Tablo 8. Umutsuzluk Düzeyinin Yaşam Doyumu Üzerine Etkisine İlişkin Çoklu Regresyon Modeli Sonuçları

\begin{tabular}{|c|c|c|c|c|c|}
\hline \multirow[t]{2}{*}{ Model } & \multicolumn{2}{|c|}{$\begin{array}{c}\text { Standardize Edilmemiş } \\
\text { Katsayılar }\end{array}$} & \multirow{2}{*}{$\begin{array}{c}\text { Standardize } \\
\text { Edilmiş } \\
\text { Katsayılar } \\
\text { Beta } \\
\end{array}$} & \multirow[t]{2}{*}{$\mathrm{t}$} & \multirow[t]{2}{*}{ Sig. } \\
\hline & $\mathrm{B}$ & Std. Hata & & & \\
\hline (Sabit) & 1,212 & , 196 & & 6,184 &, 000 \\
\hline Geleceğe Olumsuz Bakış &,- 060 &, 035 &,- 053 & $-1,723$ &, 085 \\
\hline Geleceğe Olumlu Bakıș &, 579 &, 039 &, 450 & 14,736 &, 000 \\
\hline
\end{tabular}

Tablo 8'de görüldüğü üzere $\mathrm{p}<0,05$ olduğundan $\mathrm{H}_{2 \mathrm{a}}$ reddedilmiştir. Başka bir deyişle geleceğe olumsuz bakış düzeyinin yaşam doyumu üzerine anlamlı bir etkisi yoktur. Tabloda $\mathrm{p}<0,05$ olduğundan $\mathrm{H}_{2 \mathrm{~b}}$ desteklenmiştir. Geleceğe olumlu bakış düzeyinin yaşam doyumu üzerine pozitif yönlü anlamlı bir etkisi $(\beta=0,450) \operatorname{vardır}(p<0,05)$. Öğrencilerin geleceğe olumlu bakış düzeyine sahip olmaları yaşam doyumlarını arttırmaktadır. Geleceğe olumlu bakış düzeyi arttıkça yaşam doyumu da artmaktadır.

\section{Değişkenler Arası Korelasyon Sonuçları}

Aşağıda araştırmada kullanılan değişkenler ve alt boyutları ortalamaları, standart sapmaları ve korelasyonlar aşağıda tablo 9'da yer almaktadır.

Öncelikle tablo 9'da ortalamalara bakıldığında en yüksek ortalamaya 4,21 ile sosyallik ve uğraş bulma boyutunun sahip olduğu görülmektedir. İyimserlik ve soğukkanlılık düzeyi ile geleceğe olumsuz bakış düzeyi arasındaki korelasyon katsayıs $-0,215$ 'tir $(\mathrm{p}<0,01)$.

Tablo 9. Ortalamalar, Standart Sapmalar ve Korelasyonlar

\begin{tabular}{|c|c|c|c|c|c|c|c|c|}
\hline & $\begin{array}{c}\text { Ortal } \\
\text { ama }\end{array}$ & $\begin{array}{l}\text { Std. } \\
\text { Sapm } \\
\text { a }\end{array}$ & $\begin{array}{c}\text { Iyimser } \\
\text { lik ve } \\
\text { soğukk } \\
\text { anlılık } \\
\end{array}$ & $\begin{array}{c}\text { Kötüms } \\
\text { erlik }\end{array}$ & $\begin{array}{c}\text { Sosyalli } \\
\text { k ve } \\
\text { uğraş } \\
\text { bulma }\end{array}$ & $\begin{array}{c}\text { Geleceğe } \\
\text { Olumsuz } \\
\text { Bakış }\end{array}$ & $\begin{array}{c}\text { Geleceğe } \\
\text { Olumlu } \\
\text { Bakış }\end{array}$ & $\begin{array}{c}\text { Yaşam } \\
\text { doyumu }\end{array}$ \\
\hline \multirow{2}{*}{$\begin{array}{l}\text { İyims. ve } \\
\text { soğuk. }\end{array}$} & \multirow[t]{2}{*}{3,06} & \multirow[t]{2}{*}{,797 } & 1 &,$- 286^{* *}$ &, $171^{* *}$ &,$- 215^{k \pi}$ &, $5066^{* 7 \pi}$ &, $408^{* \pi *}$ \\
\hline & & & &, 000 &, 000 &, 000 &, 000 &, 000 \\
\hline \multirow[t]{2}{*}{ Kötüms. } & \multirow[t]{2}{*}{2,89} & \multirow[t]{2}{*}{,956 } &,$- 286^{* *}$ & 1 &,- 016 &, $601^{* \pi}$ &,$- 320^{* *}$ &,$- 267^{* \pi *}$ \\
\hline & & &, 000 & & ,601 &, 000 & ,000 & $\overline{, 000}$ \\
\hline \multirow{2}{*}{$\begin{array}{l}\text { Sosy. ve } \\
\text { uğraş }\end{array}$} & \multirow[t]{2}{*}{4,21} & \multirow[t]{2}{*}{, 885} &, $171^{* *}$ &,- 016 & 1 &,$- 188^{n \pi}$ &, $424^{* \pi 7}$ &, $158^{2 * \pi}$ \\
\hline & & & ,000 & 601 & &, 000 &, 000 &, 000 \\
\hline \multirow{2}{*}{$\begin{array}{l}\text { Geleceğe } \\
\text { Olumsuz } \\
\text { Bakıș }\end{array}$} & \multirow[t]{2}{*}{2,51} & \multirow[t]{2}{*}{,806 } &,$- 215^{* *}$ & $601^{* *}$ &,$- 188^{* *}$ & 1 &,$- 429^{* *}$ &,$- 246^{* * *}$ \\
\hline & & &, 000 & , 000 & ,000 & &, 000 &, 000 \\
\hline \multirow{2}{*}{$\begin{array}{l}\text { Geleceğe } \\
\text { Olumlu } \\
\text { Bakıș }\end{array}$} & \multirow[t]{2}{*}{3,57} & \multirow[t]{2}{*}{,712 } &, 506 &,- 320 &, 424 &,- 429 & 1 &, $473^{\prime \prime \prime}$ \\
\hline & & &, 000 & ,000 &, 000 &, 000 & &, 000 \\
\hline \multirow[t]{2}{*}{ Yaş.doy. } & \multirow[t]{2}{*}{3,13} & \multirow[t]{2}{*}{915} & $408^{* *}$ &,$- 267^{* *}$ & $158^{* *}$ &,$- 246^{* *}$ & $473^{* *}$ & 1 \\
\hline & & &, 000 &, 000 & $\begin{array}{l}, 000 \\
\end{array}$ &, 000 &, 000 & \\
\hline
\end{tabular}

Başka bir deyişle iyimserlik ve soğukkanlılık düzeyi arttıkça geleceğe olumsuz bakış düzeyi azalmaktadır. İyimserlik ve soğukkanlılık düzeyi ile geleceğe olumlu bakış düzeyi arasındaki korelasyon katsayısı 0,506 'dır $(\mathrm{p}<0,01)$. İyimserlik ve soğukkanlılık düzeyi arttıkça geleceğe olumlu bakış düzeyi de artmaktadır. İyimserlik ve soğukkanlılık düzeyi ile yaşam doyumu arasındaki korelasyon katsayısı 0,408'dir $(\mathrm{p}<0,01)$. İyimserlik ve soğukkanlılık düzeyi arttıkça yaşam doyumu da artmaktadır. 
Kötümserlik ile geleceğe olumsuz bakış düzeyi arasındaki korelasyon katsayısı 0,601 'dir(p<0,01). Kötümserlik arttıkça geleceğe olumsuz bakış düzeyi de artmaktadır. Kötümserlik ile geleceğe olumlu bakış düzeyi arasındaki korelasyon katsayısı $-0,320$ 'dir $(p<0,01)$. Kötümserlik arttıkça geleceğe olumlu bakış düzeyi azalmaktadır. Kötümserlik ile yaşam doyumu arasındaki korelasyon katsayısi $-0,267$ 'dir $(\mathrm{p}<0,01)$. Kötümserlik arttıkça yaşam doyumu azalmaktadır.

Sosyallik ve uğraş bulma düzeyi ile geleceğe olumsuz bakış düzeyi arasındaki korelasyon katsayısı -0,188'dir $(\mathrm{p}<0,01)$. Sosyallik ve uğraş bulma düzeyi arttıkça geleceğe olumsuz bakış düzeyi azalmaktadır. Sosyallik ve uğraş bulma düzeyi ile geleceğe olumlu bakış düzeyi arasındaki korelasyon katsayısı 0,424'tür $(\mathrm{p}<0,01)$. Sosyallik ve uğraş bulma düzeyi arttıkça geleceğe olumlu bakış düzeyi de artmaktadır. Sosyallik ve uğraş bulma düzeyi ile yaşam doyumu arasındaki korelasyon katsayısı 0,158'dir. Sosyallik ve uğraş bulma düzeyi arttıkça yaşam doyumu da artmaktadır.

Geleceğe olumsuz bakış düzeyi ile yaşam doyumu arasindaki korelasyon katsayısi $-0,246$ 'dır $(\mathrm{p}<0,01)$. Başka bir deyişle geleceğe olumsuz bakış düzeyi arttıkça yaşam doyumu azalmaktadır. Geleceğe olumlu bakış düzeyi ile yaşam doyumu arasındaki korelasyon katsayıs1 $0,473^{\prime}$ tür $(\mathrm{p}<0,01)$. Diğer bir ifadeyle geleceğe olumlu bakış düzeyi arttıkça yaşam doyumu da artmaktadır.

\section{Tartışma ve Sonuç}

Araştırmamızda İyimserlik, Umutsuzluk ve Yaşam doyumu değişkenleri ve alt boyutlarının sosyo-demografik özelliklere göre bir farklılık gösterip göstermediğini belirlemede nonparametrik testler olarak mann whitney u ve kruskal wallis testleri yapılmıştır. Araştırma sonuçlarımıza göre erkek öğrencilerin iyimserlik ve soğukkanlılık düzeyi kız öğrencilerden fazladır. Kız öğrencilerin erkek öğrencilere göre kötümserlik düzeylerinin daha yüksek olduğu gözlenmiştir. Bu durum farklı örneklemlerle çalışıldığında değişebilir. Not ortalaması çok yüksek olanların iyimserlik ve soğukkanlılık düzeyi diğerlerinden fazla iken, not ortalaması düşük olanların kötümserlik düzeyi diğerlerinden fazladır. Dikkat çeken bir diğer sonuçta akrabasının yanında kalan öğrencilerin kötümserlik düzeyinin diğerlerinden fazla olmasıdır. $\mathrm{Bu}$ sonuç akrabasının yanında kalan öğrencilerin okul hayatı- na yönelik motive olamadıklarını akla getirmektedir. 10. sinıfların kötümserlik düzeylerinin diğerlerinden yüksek olması bu öğrencilerin lise öğrenimlerinin ortalarında olması ile ilgili olabilir. 12. sinıfların sosyallik ve uğraş bulma düzeylerinin diğerlerinden yüksek olması bu öğrencilerin üniversiteye hazırlanmalarıyla ilişkili olabilir. Aile gelir düzeyi düşük olan öğrencilerin kötümserlik düzeylerinin diğerlerinden fazla olması bu öğrencilerin imkânlarının kısıtlı olması ile ilgili olabilir. Anne eğitim durumu lise olanların sosyallik ve uğraş bulma düzeyinin diğerlerinden yüksek olması bu öğrencilerin daha sosyal olduklarını akla getirmektedir. Ailesinin yanında kalan öğrencilerin sosyallik ve uğraş bulma düzeylerinin diğerlerinden yüksek olması ailesiyle kalan öğrencilerin sosyal çevresinin daha geniş olduğunun bir göstergesi olabilir.

Gençoğlu, Alkan ve Koçyiğit (2014) üniversite öğrencileri üzerine gerçekleştirdiği araştırmasında kız ve erkek öğrencilerin iyimserlik düzeyleri açısından farklılık olmadığını ifade etmektedir. Araştırmamızda ise erkek öğrencilerin iyimserlik ve soğukkanlılık düzeyinin kız öğrencilerden fazla olduğun ifade edilmektedir. Aynı zamanda araştırmamızda kız öğrencilerin kötümserlik düzeylerinin erkek öğrencilerden yüksek olduğu ifade edilmektedir. Belirtilen araştırma ile araştırmamız arasında ortaya çıkan bu farklılık farklı örneklemlerle çalışılmasından kaynaklanabilir. Başka bir deyişle araştırmamızın uygulaması lise öğrencileri üzerine iken, belirtilen araştırma üniversite öğrencilerine uygulanmıştır.

Araştırma sonuçlarımızda anne eğitimi yüksek lisans olanların geleceğe olumsuz bakış düzeyinin diğerlerinden yüksek olması dikkat çeken bir sonuçtur. Not ortalaması çok düşük olanların geleceğe olumsuz bakışlarının yüksek olması kendilerini yetersiz görmeleri ile ilgili olabilir. Bu öğrencilerin notları çok düşük olduğu için umutsuzluğa kapıldığ 1 düşünülebilir. Arkadaşlarıyla kalan öğrencilerin geleceğe olumsuz bakış düzeyinin yüksek olması bu öğrencilerin aile ortamından uzak kalması ile ilişkili olabilir. Aile gelir düzeyleri düşük öğrencilerin diğerlerine göre geleceğe daha olumsuz bakması bu öğrencilerin hayattaki olanaklarının azlığı ile ilgili olabilir. 12. sınıfların geleceğe olumlu bakış düzeylerinin daha yüksek olması bu öğrencilerin üniversite sinavlarına hazırlanan ve üniversiteye gidebilecek kişiler olması ile ilişkili olabilir. Not ortalaması çok yüksek olanların geleceğe olumlu bakış düzeylerinin fazla olması bu öğrencilerin yeterli bilgiye sahip olmaları ile ilgili olabilir. 
Gençay (2009) ve Doğan (2012) öğretmen adayı üniversite öğrencileri üzerine gerçekleștirdiği araştırmalarda umutsuzluk düzeylerinin kız ve erkek öğrencilere göre farklılık göstermediğini ifade etmektedirler. Yani umutsuzluk düzeyinin cinsiyete göre farklılık göstermediğini belirlemişlerdir. Araştırmamızda da umutsuzluk alt boyutlarının cinsiyete göre farklılık göstermediği ifade edilmektedir. Bu açıdan bulunan sonuçlar benzerlik göstermektedir.

Uz Baş ve Kabasakal (2013) farklı üniversitelerin eğitim fakültelerindeki üniversite öğrencilerine uyguladığ 1 araştırmasında erkek öğrencilerin umutsuzluk düzeyinin kızlara göre daha yüksek olduğunu ifade etmektedir. Ayrıca araştırmasında ekonomik gelirini yeterli olarak görenlerin yeterli görmeyenlere göre umutsuzluk düzeylerinin daha düşük olduğunu ifade etmektedir. Araştırmamızda ise belirtilen araştırmadan farklı olarak umutsuzluk alt boyutları cinsiyete göre farklılık göstermemektedir. Ancak belirtilen bu araştırmaya benzer olarak araştırmamızda aile gelir düzeyi düşük öğrencilerin geleceğe olumsuz bakış düzeylerinin diğerlerinden yüksek olduğu ifade edilmektedir.

Tümkaya, Çelik ve Aybek (2011) lise öğrencileri üzerine gerçekleştirdiği araştırmasında umutsuzluk düzeyinin cinsiyete, sınıfa ve gelir düzeyine göre farkl1lık göstermediğini ifade etmektedir. Araştırmamızda da umutsuzluk alt boyutları cinsiyete göre farklılık göstermemektedir. Ancak belirtilen araştırmadan farklı olarak araştırmamızda 12. sinıfların geleceğe olumlu bakış düzeylerinin diğerlerinden yüksek olduğu ifade edilmektedir. Ayrıca araştırmamızda aile gelir düzeyi düşük olan öğrencilerin geleceğe olumsuz bakış düzeylerinin diğerlerinden daha fazla olduğu ifade edilmektedir.

Araştırma sonuçlarımızda 9.sınıfların yaşam doyumlarının yüksek çıkması bu öğrencilerin lise yıllarının başlarında olmaları ile ilişkili olabilir. Baba eğitim durumu lise olanların yaşam doyumlarının yüksek olması bu öğrencilerin sosyal olmalarıyla ilişkili olabilir. Not ortalaması çok yüksek olanların yaşam doyumlarının fazla olması kendilerini yeterli gördüklerini ortaya koymaktadır. Dikkat çeken bir sonuçta arkadaşlarıyla birlikte kalan öğrencilerin yaşam doyumlarının yüksek çıkmasıdır. Bu durum bu öğrencilerin kendilerini daha bağımsız hissetmesi ile ilgili olabilir. Aile gelir düzeyi yüksek öğrencilerin yaşam doyumlarının yüksek olması imkân ve olanaklarının fazlalığı ile açıklanabilir.
Tuzgöl Dost (2007) üniversite öğrencileri üzerine gerçekleştirdiği araştırmasında yaşam doyumunun cinsiyete göre farklılık gösterdiğini ve kızların yaşam doyumlarının erkeklerden yüksek olduğunu ifade etmektedir. Aynı zamanda yaşam doyumunun alg1lanan akademik başarıya göre farklılık gösterdiğini belirtmektedir. Araştırmasında algılanan akademik başarısı yüksek öğrencilerin yaşam doyumlarının da yüksek olduğunu ifade etmektedir. Araştırmamızda ise yaşam doyumunun cinsiyete göre farklllık göstermediği ifade edilmektedir. Bu durum uygulama yapılan kesimlerin farklı olmasından kaynaklanabilir. Başka bir deyişle belirtilen araştırma üniversite öğrencilerine uygulanmışken araştırmamız lise öğrencilerine uygulanmıştır. Ancak belirtilen araştırma ile benzer olarak araştırmamızda da not ortalaması çok yüksek olanların yaşam doyumlarının diğerlerinden fazla olduğu ifade edilmektedir.

Gençay (2009) ve Recepoğlu (2013) gerçekleştirdiği araştırmalarında cinsiyet değişkenine göre öğretmen adaylarının yaşam doyumlarının farklılık gösterip göstermediğini araştırmışlardır. Öğretmen adaylarının yaşam doyum düzeylerinin cinsiyete göre farklılık gösterdiğini bulmuşlardır. Bu kapsamda bayan öğretmen adaylarının yaşam doyum düzeylerinin erkek öğretmen adaylarından yüksek olduğunu belirlemişlerdir. Araştırmamızda ise yaşam doyumu cinsiyete göre farklılık göstermemektedir. Bu durum araştırmaların uygulamalarının farklı kesimlere yapılmasından kaynaklanabilir. Diğer bir ifadeyle araştırmamız lise öğrencileri üzerine, belirtilen araștırmalar ise öğretmen adayı üniversite öğrencilerine yapılmış olması bu farklılığa yol açmış olabilir.

Tümkaya, Çelik ve Aybek (2011) lise öğrencilerinin yaşam doyumlarının cinsiyete ve sinıf düzeyine göre farklılık göstermediğini ifade etmektedir. Ayrıca Tümkaya, Çelik ve Aybek (2011) lise öğrencilerinin yaşam doyumunun gelir düzeyine göre farklılık gösterdiğini bulmuştur. Araştırmamızda da benzer olarak yaşam doyumunun cinsiyete göre farklılık göstermediği ifade edilmektedir. Belirtilen araştırmadan farklı olarak araştırmamızda yaşam doyumunun sınıf düzeyine göre farklılık gösterdiği ifade edilmektedir. Araştırmamızda 9.sınıfların yaşam doyumu düzeylerinin diğerlerinden yüksek olduğu ifade edilmektedir. Belirtilen araştırmaya benzer olarak araştırmamızda yaşam doyumunun gelir düzeyine göre farklılık gösterdiği ifade edilmektedir. Araştırmamızda aile gelir düzeyi yüksek olan öğrencilerin yaşam doyumlarının diğerlerinden yüksek olduğu belirtilmektedir. 
Araştırmamızda iyimserlik ölçeği alt boyutları olan "İyimserlik ve Soğukkanlılık", "Kötümserlik" ve "Sosyallik ve Uğraş Bulma”nın yaşam doyumu üzerine etki edip etmediğine ilişkin çoklu regresyon testi yapılmıştır. İyimserlik ve soğukkanlılık düzeyinin yaşam doyumu üzerine pozitif yönlü anlamlı bir etkisi $(\beta=0,344)$ olduğu gözlenmiştir $(\mathrm{p}<0,05)$. Öğrencilerin iyimserlik ve soğukkanlılık algısına sahip olması yaşam doyumlarını arttırmaktadır. İyimserlik ve soğukkanlılık algısı arttıkça yaşam doyumu da artmaktadır. Kötümserlik düzeyinin yaşam doyumu üzerine negatif yönlü anlamlı bir etkisi $(\beta=-0,167)$ olduğu gözlenmiştir $(\mathrm{p}<0,05)$. Öğrencilerin kötümserlik algısına sahip olması yaşam doyumlarını azaltmaktadır. Kötümserlik algısı arttıkça yaşam doyumu azalmaktadır. Sosyallik ve uğraş bulma düzeyinin yaşam doyumu üzerine pozitif yönlü anlamlı bir etkisi $(\beta=0,096)$ olduğu gözlenmiştir $(\mathrm{p}<0,05)$. Öğrencilerin sosyallik ve uğraş bulma algısına sahip olması yaşam doyumlarını arttırmaktadır. Sosyallik ve uğraş bulma arttıkça yaşam doyumu da artmaktadır. Çoklu regresyon modeli beta katsayılarına bakıldığında yaşam doyumu üzerine en fazla iyimserlik ve soğukkanlılık boyutunun etki ettiği $(\beta=0,344)$ gözlenmiştir. Ayr1ca yaşam doyumu üzerine en az sosyallik ve uğraş bulma boyutunun etki ettiği $(\beta=0,096)$ gözlenmiştir. Başka bir deyişle iyimserlik ve soğukkanlılık algısının yaşam doyumu üzerinde daha etkili olduğu söylenebilir.

Jiang vd. (2014) ve Gülcan \& Nedim Bal (2014) gerçekleştirdiği araştırmalarda iyimserlik düzeyinin yaşam doyumu üzerine pozitif yönlü anlamlı bir etkisi olduğunu ifade etmektedirler. Aynı zamanda korelasyon sonuçlarına göre iyimserlik ile yaşam doyumu arasında pozitif yönlü anlamlı bir ilişki olduğunu belirtmektedirler. Sapmaz ve Doğan (2012) üniversite öğrencileri üzerine gerçekleştirdiği araştırmasında iyimserlik ile yaşam doyumu arasında pozitif yönlü bir ilişki olduğunu ifade etmektedir. Jiang vd. (2014) araştırmasında korelasyon sonuçlarına göre kötümserlik ile yaşam doyumu arasında negatif yönlü anlamlı bir ilişki olduğunu ifade etmektedir. Belirtilen araştırmaların sonuçlarına benzer sonuçlar araştırmamızda da elde edilmiştir. Araştırmamızda iyimserlik alt boyutlarından iyimserlik ve soğukkanlılık düzeyinin yaşam doyumuna pozitif yönlü anlamlı etkisi olduğu ifade edilmektedir. Aynı zamanda araştırmamızda iyimserlik ve soğukkanlılık düzeyi ile yaşam doyumu arasında pozitif yönlü korelasyon olduğu ifade edilmektedir. Yine araştırmamızda kötümserlik ile yaşam doyumu arasında negatif yönlü korelasyon olduğu belirtilmiştir. Bulduğumuz sonuçlar yukarıda belirtilen araştırmaların sonuçları ile benzerlik göstermektedir.

Araştırmamızda umutsuzluk ölçeği alt boyutları olan "Geleceğe Olumsuz Bakış" ve "Geleceğe Olumlu Bakış" yn yaşam doyumu üzerine etki edip etmediğine ilişkin çoklu regresyon testi yapılmıştır. Geleceğe olumsuz bakış düzeyinin yaşam düzeyi üzerine anlamlı bir etkisi olmadığı gözlenmiştir. Geleceğe olumlu bakış düzeyinin yaşam doyumu üzerine pozitif yönlü anlamlı bir etkisi $(\beta=0,450)$ olduğu gözlenmiştir $(\mathrm{p}<0,05)$. Öğrencilerin geleceğe olumlu bakış algısına sahip olmaları yaşam doyumlarını arttırmaktadır. Geleceğe olumlu bakış algısı arttıkça yaşam doyumu da artmaktadır. Gündoğar vd. (2007) ve Gençay (2009) üniversite öğrencileri üzerine gerçekleştirdiği araştırmalarında umutsuzluk ile yaşam doyumu arasında negatif yönlü bir korelasyon olduğunu ifade etmektedir. Tümkaya, Çelik ve Aybek (2011) lise öğrencileri üzerine gerçekleştirdiği araştırmasında umutsuzluk ile yaşam doyumu arasında negatif yönlü bir korelasyon olduğunu belirtmektedir. Belirtilen bu araştırmalara benzer olarak araştırmamızda korelasyon sonuçlarına göre umutsuzluk alt boyutlarından geleceğe olumsuz bakış ile yaşam doyumu arasında negatif yönlü korelasyon olduğu ifade edilmektedir. Strauss vd. (2014) sigorta şirketinde çalışanlar üzerine gerçekleştirdiği araştırmasında umut ile iyimserlik arasında pozitif yönlü bir ilişki olduğunu belirtmektedir. Araştırmamızda korelasyon sonuçlarımıza göre iyimserlik ve soğukkanlılık boyutu ile geleceğe olumlu bakış arasında pozitif yönlü korelasyon olduğu ifade edilmektedir.

\section{Kaynakça}

Akgündüz, Y. (2013). Konaklama İşletmelerinde İş Doyumu, Yaşam Doyumu ve Öz Yeterlilik Arasındaki İlişkinin Analizi. Celal Bayar Üniversitesi Sosyal Bilimler Dergisi, Cilt 11, Say1 1,180-204.

Alarcon, G.M., Bowling, N.A. \& Khazon, S. (2013). Great Expectations: A Meta-analytic Examination of Optimism and Hope. Personality and Individual Differences, 54, 821-827. 
Aydın, G. ve Tezer, E. (1991). İyimserlik, Sağlık Sorunları ve Akademik Başarı İlişkisi. Psikoloji Dergisi, 7, 2-9.

Beck, A.T., Lesker, D. ve Trexler, M. (1974). The Hopelessness Scale. Journal of Consulting and Clinical Psychology, 42, 861-874.

Black, J. ve Reynolds, W.M. (2013). Examining the Relationship of Perfectionism, Depression, and Optimism: Testing for Mediation and Moderation. Personality and Individual Differences, 54, 426-431.

Carretta, C.M., Ridner, S.H. ve Dietrich, M.S. (2014). Hope, Hopelessness, and Anxiety: A Pilot Instrument Comparison Study, Archives of Psychiatric Nursing. 28, 230-234.

Carver, C.S. (2014). Self-control and Optimism Are Distinct and Complementary Strengths. Personality and Individual Differences, 66, 24-26.

Çeçen, A.R. (2007). Üniversite Öğrencilerinin Cinsiyet ve Yaşam Doyumu Düzeylerine Göre Sosyal ve Duygusal Yalnızlık Düzeylerinin İncelenmesi. Mersin Üniversitesi Eğitim Fakültesi Dergisi, Cilt 3, Sayı 2, 180-190.

Daniel, S.S. ve Goldston, D.B. (2012). Hopelessness and Lack of Connectedness to Others as Risk Factors for Suicidal Behavior Across the Lifespan: Implications for Cognitive-Behavioral Treatment. Cognitive and Behavioral Practice, 19, 288-300.

Diener, E., Emmons, R.A., Larsen, R.J. ve Griffin, S. (1985). The Satisfaction With Life Scale. Journal of Personality Assessment, 49,1, 71-75.

Doğan, P. (2012). Resim Öğretmeni Adaylarının Umutsuzluk Düzeylerinin İncelenmesi. M.Ü. Atatürk Eğitim Fakültesi Eğitim Bilimleri Dergisi, Sayı $36,115-127$.

Eicher, V., Staerkle, C. ve Clemence, A. (2014). I Want to Quit Education: A Longitudinal Study of Stress and Optimism as Predictors of School Dropout Intention. Journal of Adolescence, 37, 1021-1030.
Fastame, M.C., Penna, M.P. ve Hitchcott, P.K. (2015). Life Satisfaction and Social Desirability Across the Late Life Span: What Relationship?. Quality of Life Research, 24, 1, 241-244.

Gençay, S. (2009). Beden Eğitimi Öğretmeni Adaylarının Umutsuzluk ve Yaşam Doyumlarının Bazı Değişkenler Açısından İncelenmesi. Elektronik Sosyal Bilimler Dergisi, C.8, S.27, Kış, 380-388.

Gençoğlu, C., Alkan, E. ve Koçyiğit, M. (2014). Bir Mit Olarak İyimserlik; Kızlar Mı Erkekler Mi Daha İyimser?, Elektronik Sosyal Bilimler Dergisi. Cilt 13, Say1 50, 129-138.

Gülcan, A. ve Nedim Bal, P. (2014). Genç Yetişkinlerde İyimserliğin Mutluluk ve Yaşam Doyumu Üzerindeki Etkisinin İncelenmesi. Asya Öğretim Dergisi, 2(1), 41-52.

Gündoğar, D., Gül, S.S., Uskun, E., Demirci, S. ve Keçeci, D. (2007). Üniversite Öğrencilerinde Yaşam Doyumunu Yordayan Etkenlerin İncelenmesi. Klinik Psikiyatri, 10, 14-27.

Hanna, D., White, R., Lyons, K., McParland, M.J., Shannon, C. ve Mulholland, C. (2011). The Structure of the Beck Hopelessness Scale: A Confirmatory Factor Analysis in UK Students. Personality and Individual Differences, 51, 17-22.

Jiang, W., Li, F., Jiang, H., Yu, L., Liu, W., Li, Q. ve Zuo, L. (2014). Core Self-Evaluations Mediate the Associations of Dispositional Optimism and Life Satisfaction. Plos One, 9(6), 1-6.

Kim, E.S., Chopik, W.J. ve Smith, J. (2014). Are People Healthier If Their Partners Are More Optimistic? The Dyadic Effect of Optimism On Health Among Older Adults. Journal of Psychosomatic Research, $76,447-453$.

Kodan, S. (2013). Üniversite Öğrencilerinde Umutsuzluk ve Akılcı Olmayan İnanışlar Arasındaki İlişkinin Çeşitli Değişkenler Açısından İncelenmesi. CBÜ Sosyal Bilimler Dergisi, Cilt 11, Sayı 2, Ağustos, $175-190$. 
Köker, S. (1991). Normal ve Sorunlu Ergenlerin Yaşam Doyumu Düzeylerinin Karşılaştırılması. Basılmamış Yüksek Lisans Tezi, Ankara Üniversitesi Sosyal Bilimler Enstitüsü, Ankara.

Lester, D. (2015). Hopelessness in Adolescents. Journal of Affective Disorders, 173, 221-225.

Lu, A., Hong, X., Yu, Y., Ling, H., Tian, H., Yu, Z. \& Chang, L. (2015). Perceived Physical Appearance and Life Satisfaction: A Moderated Mediation Model of Self-esteem and Life Experience of Deaf and Hearing Adolescents. Journal of Adolescence, 39, 1-9.

Matud, M.P., Bethencourt, J.M. ve Ibanez, I. (2014). Relevance of Gender Roles in Life Satisfaction in Adult People, Personality and Individual Differences. 70, 206-211.

Recepoğlu, E. (2013). Öğretmen Adaylarının Yaşam Doyumları ile Öğretmenlik Mesleğine İlişkin Tutumları Arasındaki İlişkinin İncelenmesi. Hacettepe Üniversitesi Eğitim Fakültesi Dergisi, Özel Sayı 1, 311-326.

Sapmaz, F. ve Doğan, T. (2012). Mutluluk ve Yaşam Doyumunun Yordayıc1sı Olarak İyimserlik. Mersin Üniversitesi Eğitim Fakültesi Dergisi, Cilt 8, Sayı 3, 63-69.

Scheier, M.F. ve Carver, C.S. (1985). Optimism, Coping, and Health: Assessment and Implications of Generalized Outcome Expectancies. Health Psychology, 4(3), 219-247.

Seber, G., Dilbaz, N., Kaptanoğlu, C. ve Tekin, D. (1993). Umutsuzluk Ölçeği: Geçerlilik ve Güvenirliği. Kriz Dergisi, 1(3), 139-142.

Smith, T.W., Ruiz, J.M., Cundiff, J.M., Baron, K.G. ve Nealey-Moore, J.B. (2013). Optimism and Pessimism in Social Context: An Interpersonal Perspective on Resilience and Risk. Journal of Research in Personality, 47, 553-562.

Spirito, A. ve Overholser, J.C. (2003). Evaluating and Treating Adolescent Suicide Attempters: From Research to Practice. Academic Press, USA.
Strauss, K., Niven, K., McClelland, C.R. ve Cheung, B.K.T. (2014). Hope and Optimism in the Face of Change: Contributions to Task Adaptivity. Journal of Business and Psychology, 12, December.

Turgut, H. ve Mert, İ.S. (2014). Çalışanların İş Doyumlarının Yaşam Doyumları Üzerindeki Etkisi: Kamu ve Özel Sektörde Bir Alan Araştırması. Süleyman Demirel Üniversitesi İktisadi ve İdari Bilimler Fakültesi Dergisi, C.19, S.4, 77-91.

Tuzgöl Dost, M., (2007). Üniversite Öğrencilerinin Yaşam Doyumunun Bazı Değişkenlere Göre İncelenmesi. Pamukkale Üniversitesi Eğitim Fakültesi Dergisi, 2, 22, 132-143.

Tümkaya, S. (2005). Ailesi Yanında ve Yetiştirme Yurdunda Kalan Ergenlerin Umutsuzluk Düzeylerinin Karşılaştırılması. Türk Eğitim Bilimleri Dergisi, 3(4), 445-459.

Tümkaya, S., Çelik, M. ve Aybek, B. (2011). Lise Öğrencilerinde Boyun Eğici Davranışlar, Otomatik Düşünceler, Umutsuzluk ve Yaşam Doyumunun İncelenmesi. Ç.Ü. Sosyal Bilimler Enstitüsü Dergisi, Cilt 20, Sayı 2, 77-94.

Uz Baş, A. ve Kabasakal, Z. (2013). Öğretmen Adaylarında Umutsuzluk ve Algilanan Sosyal Destek. Eğitim ve Öğretim Araştırmaları Dergisi, Cilt 2, Sayı 1, Şubat, 19-26.

Zhang, J., Zhao, S., Lester, D. ve Zhou, C. (2014). Life Satisfaction and its Correlates Among College Students in China: A Test of Social Reference Theory. Asian Journal of Psychiatry, 10, 17-20.

Zhao, J., Wang, Y. ve Kong, F. (2014). Exploring the Mediation Effect of Social Support and Self-esteem on the Relationship Between Humor Style and Life Satisfaction in Chinese College Students. Personality and Individual Differences, 64, 126-130.

Velting, D.M. (1999). Personality and Negative Expectancies: Trait Structure of the Beck Hopelessness Scale. Personality and Individual Differences, 26, 913-921. 